\title{
Metacognitive Strategies of Developing the Reading Competence of Students of Institutions of Higher Education
}

\section{Метакогнітивні стратегії розвитку читацької компетентності в студентів закладів вищої освіти}

Tamiliia Dotsevych

Dr. in Psychology,

Professor

\author{
Тамілія Доцевич \\ доктор психологічних наук, \\ професор
}

E-mail: tamiliia.dotsevych@gmail.com orcid.org/0000-0001-6424-7801

\author{
Pereiaslav-Khmelnytskyi \\ Hryhorii Skovoroda \\ State Pedagogical University \\ $\triangle$ 30, Sukhomlynskyi Str., \\ Pereiaslav-Khmelnytskyi, Kyiv Reg., \\ Ukraine, 08401
}

ДВНЗ «Переяслав-Хмельницький

державний педагогічний університет імені Г.С. Сковороди»

$\checkmark$ вул. Сухомлинського, 30, Переяслав-Хмельницький,

Київська обл., Україна, 08401

Original manuscript received September 29, 2018

Revised manuscript accepted September 11, 2019

\begin{abstract}
Introduction. The paper presents the peculiarities and advantages of using the metacognitive strategies to develop the reading competence in students of pedagogical universities in the process of educational-vocational training; the notion "strategies of reading" is clarified, the basic structural components are determined; the functions of the metacognitive strategies, their role when working with scientific texts are considered. The theoretical approaches to the metacognitive strategies are represented, their functions, their role in understanding scientific texts. The notions and meanings of the metacognitive skills and metacognitive strategies are
\end{abstract}


revealed. The metacognitive skills can be considered as an integration of the ability to understand scientific texts and metalinguistic erudition, i. e. as a set of knowledge about the text and ability to work with the text. The paper presents the author's programme of forming metalinguistic strategies when working with scientific texts.

Results \& Discussions. Erudition in the metastrategies is connected with the ability to understand complex verbal material of scientific character. The attention is paid to the fact that due to reflection the reader through speech experience penetrates into the essence of the text, reaches its comprehension. It is shown that metacognitive knowledge such as erudition in strategies and techniques of metacognition is connected with the ability to understand complex verbal material of scientific character. It is underlined that using actively the metacognitive strategies of management of one's own cognitive activity, awareness of the process of implementing these strategies positively are connected with the ability to understand scientific texts and can be considered as a determinant of such an ability. It is noted that mastering the metacognitive strategies, their variability foresees knowledge and understanding of the structure of texts, their types, high ability to understand texts and variability of different metacognitive operations when working with the text material. Metalinguistic erudition, i.e. the set of knowledge of the text and the ability to work with it allows mastering different texts of vocational orientation quickly and effectively. Metalinguistic strategies as well the ability of the specialist to his/her own professional activities are positively connected with the ability to work effectively with the text material and the ability to process complex scientific texts.

Key words: strategies of reading, metalinguistic abilities, metacognitive strategies, reading and understanding of scientific texts, reflection, monitoring.

\section{Вступ}

Мовленнєва діяльність людини має чотири види прояву: аудіювання, говоріння, читання, письмо. Читання як один з означених психолінгвістичних феноменів знаходиться у взаємозв'язку i взаємообумовленості 3 іншими видами мовленнєвої діяльності. Найменш вивченим компонентом серед цих видів $є$ читання, зокрема читання наукових текстів студентами. Проблема читання в працях багатьох східноєвропейських і євразійських психолінгвістів розглядається як складова частина аудіювання (Залевская, 2005; Красных, 2001 та ін.), а не як самостійне мовленнєво-мисленнєвомовне явище.

Методологічною основою дослідження метакогнітивних стратегій читання $€$ психолінгвістична теорія мовленнєвої 
Metacognitive Strategies of Developing the Reading Competence...

діяльності (Выготский, 2000; Зимняя, 2001; Леонтьев, 2003; Рубинштейн, 2000) та ін.

Метакогнітивні стратегії мають велике значення в опануванні студентами вмінням читати й розуміти тексти; в оволодінні читацькою компетентністю. Особливо важливого значення набуває читацька компетентність у роботі 3 науковими текстами, що відіграє важливу роль у професійно-інтелектуальному і когнітивнокреативному становленні майбутніх фахівців.

Читацька компетентність студентів закладів вищої освіти має ряд особливостей. Завдяки своїй міждисциплінарній природі вона сприяє не тільки становленню професійної компетентності, але $є$ також фундаментом для самостійно-пошукової, науково-дослідної роботи студентів.

Теоретичний аналіз сучасних досліджень, опублікованих у різних журналах світу, монографіях $з$ психолінгвістики, присвячених стратегіям читання, засвідчив, що проблема ця розкривається багатоаспектно.

Стратегіям читання в межах метакогнітивного підходу присвячені дослідження зарубіжних вчених (Chen, 1992; Ghahari \& Basanjideh, 2015). Проблема розуміння наукових i навчальних текстів розглядалася в працях Я. Мікк (Микк, 1981), Г. Богіна (Богин, 1989), В. Нароліної (Наролина, 1982), Н. Чепелєвої (Чепелева, 1992) та ін. Вивченню метакогнітивної регуляції розуміння наукових текстів присвячено дослідження О. Лазаревої (2012). Проте більшість розвідок, присвячених читанню, зокрема метакогнітивним стратегіям у розвитку читацької компетентності, представлено зарубіжними вченими: психологами, психолінгвістами та лінгвістами.

Проблематика стратегій читання, вивчення індивідуальних відмінностей у використанні стратегії розуміння прочитаного підлітками, пов'язані з навичками читання, рівнем освіти і статтю досліджували Denton, Wolters, York, Swanson, Kulesz \& Francis (2015). Дослідженню стратегій читання в молодшому коледжі, серед учнів 10-х класів 3 поглибленим вивченням англійської мови в Тайвані присвячені роботи Shih, Chern, Ch.-lan \& Reynolds (2018). Автори дають рекомендації щодо поліпшення розуміння тексту, які можна застосувати для навчання учнів професійно-технічних училищ. Динаміці мовного навчання, вивчання психологічних, 
освітніх результатів усвідомлення й використання стратегій читання учнями різних вікових категорій 3 погляду навчання читанню присвячена стаття Hartman (2001). Дані цих вчених підтверджують, що метакогнітивні й когнітивні стратегії позитивно впливають на підвищення та досягнення розуміння прочитаного.

Вивчалася також проблема метакогнітивного моніторингу в дітей 7-10 років і дорослих людей у процесі читання Tsalas, Paulus \& Sodian (2015). Вченими доведено, що дорослі люди краще засвоюють і використовують можливості моніторингу та планування при навчанні, ніж діти. Розглядали метакогнітивне саморегулювання для поліпшення пізнавальної діяльності студентів, у тому числі при роботі з науковими текстами Leopold \& Leutner (2015). Автори дійшли висновку, що на глибину засвоєння матеріалу позитивно впливає саморегулювання як метакогнітивний процес.

Вивченням ефекту використання впливу метакогнітивних стратегій на ставлення учнів до читання літератури англійською мовою як іноземною присвячені дослідження Mijuskovic \& Simovic (2016). Вченими було проведено опитування студентів вищих навчальних закладів, коли і 3 якою метою вони використовують метакогнітивні стратегії читання, мають більш позитивне ставлення до процесу читання англійською мовою.

Питання ефективності впливу метакогнітивних стратегій під час оволодіння читанням учнями початкових класів вивчали K. Alenizi \& M. Alanazi (2016). Результати проекту, спрямованого на підвищення навичок читання й розуміння пояснювальних текстів представлено в роботі Elvinia \& Ocana de Castro (2017). Проблема метакогнітивних стратегій читання студентами й викладачами мови мистецтва, у співвідношенні метакогнітивних знань і їх впливу на метакогнітивні стратегії в читанні вивчалася Soodla, Jogi, \& Kikas (2017). Питанню використання метакогнітивних стратегій у читанні дорослими людьми при вивченні англійської мови, а саме, в процесі роботи над інтонацією і вимовою присвячене дослідження D. Penuela (2018).

Кількісне дослідження розуміння прочитаного студентамипершокурсниками технічних вузів 3 використанням різних метакогнітивних стратегій присвячене дослідження Seamster, Redding, Cannon, Ryder \& Purcell (1993). Респондентами були студенти інженерних професій 3 технічних відділів. Проблему 
Metacognitive Strategies of Developing the Reading Competence...

використання метакогнітивних стратегій при вивченні іноземної мови, зокрема в письмовій формі, в аспекті написання досягнень досліджував Carell (1998). Обізнаність і використання метакогнітивних стратегій читання серед студентів медичного коледжу при вивченні англійської мови, як іноземної, в Кувейті вивчав Chen (1992).

Дослідження в Україні, присвячені метакогнітивним стратегіям у розвитку в студентів закладів вищої освіти гуманітарного профілю читацької компетентності в роботі саме 3 науковими текстами, вивчені недостатньо. Але з огляду на виклики сьогодення міжнародні освітні стандарти й порівняння дослідження якості мовленнєвої підготовки учнівської та студентської молоді увійшли в практику обов'язкових заходів щодо аналізу стану освіти, включаючи всі етапи, форми й стратегії становлення мовно-мовленнєвої компетентності, a 32016 року Україна долучилася до одного 3 найбільш масових проектів - PISA (Proqramme for International Stadent Assessment), та це не знімає актуальності суто психолінгвістичного аспекту вивчення читання - одного 3 базових процесів становлення й розвитку мисленнєво-мовленнєвого потенціалу майбутніх фахівців у соціальній сфері «людина - людина», чим i мотивується актуальність запропонованого дослідження.

Аналіз наукової літератури з проблеми дослідження, власний досвід роботи підтверджує необхідність вирішувати більш активно як на теоретичному, так i прикладному рівні проблему метакогнітивних стратегій розвитку читацької компетентності щодо роботи 3 науковими текстами. Успішність оволодіння читанням у вищій школі гуманітарного профілю, а відтак i оволодіння професією багато в чому визначається саме розвиненою читацькою компетентністю - умінням працювати 3 науковими текстами, орієнтуватися в інформаційних потоках, постійно прагнути до саморозвитку й самоосвіти, самостійно, грамотно, а також своєчасно й ефективно використовувати набуту інформацію в професійній діяльності.

Mета дослідження: здійснити теоретичний аналіз проблематики метакогнітивних стратегій розвитку читацької компетентності студентів і запропонувати перевірену в емпіричному дослідженні програму розвитку метакогнітивних стратегій читання наукових текстів. 


\section{Методи дослідження}

Згідно з метою статті передбачено такі теоретичні методи, як: аналіз наукових джерел, узагальнення проаналізованої літератури та іiі систематизація; виокремлення базових положень, на яких грунтується дослідження; визначення ключових понять: «стратегії читання», «метакогнітивні стратегії», «металінгвістичні здібності», розкриття їхньої структури, функцій, взаємозв'язку та взаємообумовленості; формулювання висновків.

\section{Результати теоретичного дослідження}

У функціонуванні сучасного інформаційного простору значне місце як у професійній, так і в суспільно-корисній діяльності людини посідає мовленнєво-мисленнєва робота 3 різного роду джерелами інформації, і все більшого значення набуває читання як один 3 психолінгвістичних процесів, як мовленнєва діяльність, як мовленнєво-мовна компетентність. Володіння та користування в практиці мовлення різного роду стратегіями читання постає в комунікативних процесах кожного суб'єкта чи не найголовнішим умінням опрацювання наукової літератури.

Читання $\epsilon$ базовим компонентом, який характеризує смислові аспекти життєдіяльності кожної людини. Читання - це один 3 видів інтелектуального й духовного саморозвитку, запорука інноваційних компетенцій.

Читання й розуміння мовних значень наукових текстів стає успішнішим, якщо його процесуальність заснована на використанні ефективних стратегій читання, зокрема металінгвокогнітивних. Стратегії читання - це комплекс дій та ментальних операцій, організованих для досягнення результату повноцінного засвоєння змісту тексту. Вони включають: план, программу операцій, які здійснює читач при роботі з текстом, таких, як аналіз і синтез, аналіз набутої інформації, оцінку власного розуміння мовних значень тексту, роздуми про прочитане, ставлення до нього тощо.

Розкриваючи поняття й значення метакогнітивних стратегій у читанні, доцільно уточнити саме поняття «стратегії читання». 
Як зазначає Н. Сметаннікова, одні 3 перших висунули твердження про наявність стратегій, які керують, забезпечуючи процесс читання, сприйняття й розуміння матеріалу прочитаного, були психолінгвісти К. Гудман i П. Колерс (Сметанникова, 2005). На думку Н. Сметаннікової, саме К. Гудман акцентує, що людина, яка читає, використовує три типи інформації: зорову, що вичленовується 3 писемного мовлення; звукову, що виділяється 3 усного мовлення, а також інформацію про звуко-буквені відношення, що вичленовується з розуміння того, як пов'язані усне й писемне мовлення (Сметанникова, 2005).

Окрім цього, читачу необхідні знання про граматичну структуру мови й того, як і які можна сформулювати контекстуальні смисли на основі писемного тексту (Сметанникова, 2005).

Поняття «стратегія» зустрічаємо в О. Леонтьєва. Учений говорить про евристичні стратегії, які формуються в індивідуальному порядку під впливом специфічних завдань засвоєння інформації, умов читання, мовленнєвого й «читацького» (термін О. Леонтьєва) досвіду та розповсюджуються на тексти певного типу й певні ситуації (Леонтьев, 2003).

Ця точка зору апелює до мовленнєвого досвіду читача, що дозволяє йому самостійно визначити найбільш вдалі прийоми збирання та встановлення типу смислу. У цьому випадку зміст «стратегії читання» визначається характером структурних елементів традиційного навчально-креативного процесу, де той, хто навчається, виступає як об'єкт психологічного впливу того, хто навчає, й має інтегрувати, крім індивідуально-субєктивних, його смисли та установки в роботі з мовним матеріалом наукового тексту.

П. Біммель визначає стратегію як план «ментальних дій для досягнення власної мети». Автор розглядає стратегію як програму, яка усвідомлена, цілеспрямована й у конкретній реалізації може бути розвинена на декілька позицій (Bimmel \& Rammpilon, 2000). Стратегія читання - спосіб досягнення мети розуміння писемного мовлення й вичленування інформації, що вибирається свідомо й реалізується на основі індивідуального плану чітко визначених ментальних дій.

Метакогнітивні стратегії - навички найвищого рівня складності, основними функціями яких $є$ інтеграція навичок 
нижчого рівня та саморегуляція й саме оцінювання процесу пізнання (Seamster et al., 1993).

Метакогнітивні стратегії розглядаються О.В. Лазаревою як стратегії, що сприяють усвідомленню себе як суб'єкта наукової та когнітивно-креативної діяльності, що регулюють розвивальнопошукову. Такі стратегії актуалізуються у випадку неможливості досягнення результату мисленнєвого завдання, виконують функції цілепокладання, планування, моніторингу, оцінки й контролю. Якщо розуміння матеріалу не відбувається, то підключаються інші когнітивні стратегії (Лазарева, 2012).

Метою й результатом читання є розуміння прочитаного тексту. В психології (Костюк, 1988) розуміння розглядає як опосередкований аналітико-синтетичний процес, який містить у собі виділення «смислових меж» і поєднує їх у єдине ціле як процес мислення, спрямований на вирішення завдань, що стоять перед особистістю, уміння як осмислення продуктів опосередкованого й узагальненого відображення зв'язків, процес й ефект пізнавальних процесів.

В.І. Нароліною відмічено, що внаслідок мисленнєвої переробки текстової інформації в читача відбувається створення деякої певної моделі тексту, яка становить скомпресоване до «тематичних смислових точок» тематичне утворення чи смисл сприйнятого (Наролина, 1982).

О.В. Лазаревою було виділено функції метакогнітивних стратегій у процесі розуміння наукового тексту, а саме:

1) на етапі «передчитання» реалізується метакогнітивна стратегія планування, яка передбачає реалізацію таких функцій, як визначення етапів, тривалості роботи з текстом, прогнозування можливих труднощів, вибір релевантних стратегій розуміння, залучення фонових знань, визначення цілей розуміння тексту й показників, на основі яких згодом здійснюється спостереження за результативними й процесуальними характеристиками розуміння тексту, за просуванням у засвоєнні й розумінні інформації;

2) на етапі «читання» реалізуються метакогнітивні стратегії управління інформацією, моніторингу, виправлення помилок, які виконують такі функції, як поточна оцінка правильності розуміння, виявлення суперечливої інформації та помилкових висновків, контроль, активізація пізнавальних процесів і когнітивних стратегій, поточний контроль досягнення мети й результату розуміння, оцінка 
ефективності застосовуваних стратегій, прийняття рішення про необхідність зміни плану роботи;

3) на етапі «постчитання» здійснюється метакогнітивна стратегія оцінки, яка виконує функції визначення необхідності корекції результату, виправлення помилок у розумінні тексту після виконання завдання, активізації та залучення фонових, а також включення нових знань у досвід, оцінки ефективності використаних когнітивних стратегій, винесення судження про доцільність їхнього використання в майбутньому, вираження ставлення до себе як до суб'єкта розуміння (Лазарева, 2012).

Проблему металінгвістичної компетенції у складі лінгвістичної компетентності викладача-лінгвіста вищої школи розглядали й педагоги, зокрема Ю.А. Пірвердієва. Вона визначає металінгвістичну компетенцію як багатокомпонентне явище, яке передбачає володіння певними лінгвістичними системними знаннями, термінологічного апарату предметної області лінгвістики (когнітивний компонент), навичками та вміннями, наявності здатності до виконання професійно орієнтованої мовленевої діяльності, залучення до професійної комунікації (прагматичний компонент),готовність до здійснення спостереження за власним мовленням та мовленням студентів та їх аналізу (рефлексивний компонент), а також оволодіння вміннями передавати знання в навчальному процесі адекватними мовними засобами залежно від навчальної ситуації(дидактичний, адаптивний компонент). Але, розглядаючи металінгвістичну компетенцію у складі лінгвістичної компетентності , зміст когнітивного компонента, автор не виділяє окремо метакогнітивні стратегії навчання іноземній мові, зокрема читанню (Пирвердиева, 2011).

Г.І. Богін розглядає рефлексію як діяльність над власним досвідом, яка $\epsilon$ джерелом нового досвіду. У процесі читання завдяки рефлексії читач через мовленнєвий досвід, уявлення й категорії предметно-практичної діяльності проникає в зміст тексту, досягає його розуміння (Богин, 1989). На думку Г.А. Кузнєцової, в процесі формування стратегічної компетенції у читанні беруть участь компенсаційні, метакогнітивні та когнітивні стратегії, екстралінгвістичні засоби, візуальні опори, слова-сигнали, стиль автентичного тексту, а також дії антиципації та процесу рефлексії (Кузнецова, 2004). 
Антиципація, у свою чергу, $є$ основоположним чинником при відборі текстового матеріалу для формування стратегічної компетенції в читанні.

У читанні й розумінні наукових текстів вагому роль відіграють металінгвістичні здібності - вища форма функціонування лінгвістичних здібності, які включають обізнаність у особливостях інтерпретації, репродукції, створення й трансформації текстової інформації, рефлексію перебігу цих процесів і проявляється у високому рівні здатності до їхньої саморегуляції.

Характеристика металінгвістичних здібностей здійснюється науковцями із залученням явища компетентності, насамперед читацької, контекстуальної, креативно-конотативної, евристичної, комунікативно-стилістичної тощо.

На думку Н.В. Чепелєвої, ефективність читання буде можливою за умови розвиненої читацької компетентності як системи якостей мовної особистості, що дозволяє ефективно взаємодіяти 3 письмовим повідомленням, 3 контекстуальною інформацією в цілому. Зазначений автор до структури читацької компетентності відносить когнітивну, комунікативну й операщіональну складові, кожна з яких має свої специфічні особливості (Чепелева, 1992).

Когнітивна читацька компетентність включає лінгвістичний компонент, тобто знання мови, якою написаний текст (достатній лексичний запас, граматичні знання, співвідношення слів 3 об'єктами, здатність сприймати переносне значення слів). До цього виду компетентності входить також так зване «текстове знання», яке передбачає знайомство з теорією тексту, наявність уявлень про його смислову структуру, способи кодування інформації в тексті тощо. Н.В. Чепелєва зауважує, що важливою умовою розуміння тексту $\epsilon$ також наявність у читача деякого попереднього знання, інформованості про ту предметну область, якій присвячено текст. Автором підкреслено, що когнітивна компетентність неможлива без наявності в читача фонового знання, тобто знання суміжних галузей, загальнокультурної компетентності, які дозволяють дослідити приховані натяки, тематичні та смислові асоціації, що, в свою чергу, сприяє більш глибокому й емоційно насиченому розумінню (Чепелева, 1992).

Комунікативна складова читацької компетентності забезпечує діалогічну взаємодію читача 3 текстом (установка на діалог 3 
Metacognitive Strategies of Developing the Reading Competence...

автором за допомогою письмового повідомлення, сформовані діалогічні реакції на текст, опитувально-відповідальна процедура, уміння передбачати подальший розвиток змісту, висувати гіпотези, припущення, оцінювати текст чи трансформувати його в певному творчому аспекті). Н.В. Чепелєвою підкреслено, що необхідною ланкою комунікативної компетентності $\epsilon$ контекстуальна й міжтекстова компетентність, тобто здатність виявляти інтертекстуальні характеристики повідомлення, яка забезпечує діалогічний характер читання завдяки зануренню читача в загальнокультурний контекст. Окрім зазначеного, комунікативна читацька компетентність включає сформовані інтелектуальнокогнітивні особистісні структури читача (спрямованість, ціннісні орієнтації, мотиви, читацькі інтереси й установки) (Чепелева, 1992).

Операціональна читацька компетентність включає в себе техніку читання й володіння основними операціями читання, до яких автором віднесено здатність до: а) структурування інформації, що припускає виділення окремих текстових елементів i встановлення смислових зв'язків між ними; б) стиснення змісту, що забезпечує виділення в тексті смислових опорних пунктів, у яких узагальнено зміст окремих фрагментів тексту; в) смислового згрупування матеріалу, що дозволяє виділити в тексті окремі смислові теми й підтеми, а за допомогою операції семантичного зважування - встановити їхню смислову цінність, контекстуальну навантаженість у конкретному тексті; г) переструктурування текстового матеріалу, що забезпечує встановлення ієрархії смислів повідомлення, спричиняючи побудову внутрішньої (смислової) його структури, що іє одним із визначальних результатів читання, а також перебудову текстової інформації, що допомагає зв'язати сприйняту інформацію з наявними в читача знаннями, його досвідом, оскільки структура текстової інформації не завжди відповідає підструктурам попереднього досвіду людини. (Чепелева, 1992).

Проблему розвитку здатності до ефективного читання та розуміння тексту порушувало багато зарубіжних учених. Так, у дослідженнях С. Хозенфельд процедура «мислення вголос» пов'язана зі здатністю оперативної пам'яті утримувати прочитуваний матеріал із розумінням довгих, складнопідрядних структур, зі схильністю випускати несуттєві чи менш важливі слова в тексті, i3 позитивною самооцінкою читача (Hosenfeld, 1977). 
У дослідженнях П. Каррела, Л. Гайдусека й Т. Вайс чотири характеристики у використанні стратегій були знайдені для диференціювання більш успішних із менш успішними читачами: інтеграція, визнання аспектів структури тексту, використання загальних знань, власного досвіду, асоціативного мислення, рефлексії (Carell, Gajdusek \& Wise, 1998).

Досить популярною в метакогнітивній психології є техніка SQ3R (Survey, Question, Read, Recall and Review), суть якої полягає в первинній оперативній оценці тексту, його цілей, постановці питань про користь тексту, читання, подальшому пригадуванні ключових ідей тексту та його обговорень 3 іншими людьми. Дж. Воганом i Т. Естесем (Vaughan \& Estes, 1986) було запропоновно метод «Інсерт» (insert - ефективне читання, I - interactive, R - reading, $\mathrm{T}$ - thinking), який передбачає наявність декількох (зазвичай чотирьох) маркерів (умовних позначок) із фіксованими значеннями, внаслідок чого процес читання стає активним, актуалізується розуміння прочитаного.

3 метою розвитку в студентів вищих навчальних закладів гуманітарного профілю метакогнітивних стратегій читання наукових текстів, що забезпечують найкраще розуміння змісту прочитаного, автором було розроблено відповідну програму, яка складається 3 трьох блоків.

Перший блок - «Інформаційний» - спрямований на формування психологічної поінформованості в засобах метакогнітивної регуляції розуміння тексту. У процесі реалізації даного блоку проводяться лекції «Ефективне читання - розуміння матеріалу», «Науковий стиль мовлення: особливості й умови використання», «Метакогнітивні стратегії читання».

Другий блок програми - «Операційний» - спрямований на формування метакогнітивних стратегій, які сприяють ефективному читанню. План роботи 3 новим науковим текстом може бути представлений такими етапами:

1) «мотиваційно-установчий»: організація робочого простору, підготовка робочого місця й необхідних засобів (електронна книга, олівець, блокнот для нотаток); психологічним і психолінгвістичним субстратом цього етапу $є$ позитивна мотивація до читання й установка на цей процес; 
Metacognitive Strategies of Developing the Reading Competence...

2) «метакогнітивний»: визначення завдань і мети читання, вибір стратегій, які будуть використовуватися; планування послідовності роботи з текстом, визначення його основної ідеї, знаходження визначеної інформації, організація прочитаного матеріалу за допомогою карток, схем, таблиць;

3) «рефлексивний»: самоконтроль сприйняття й розуміння прочитаного, оцінка результатів читання.

Принципи рефлексивного блоку були побудовані на основі програми «Рефлексивний асистент» В. Хакер (Hacker, 1998), Р. Хартман (Hartman, 2001):

1) усвідомлення відносності власного рівня розуміння завдання передбачає формування суджень читача щодо повноти свого індивідуального розуміння цілей і умов читання;

2) розуміння власних інтелектуальних можливостей та обмежень стосовно якості виконання визначених у процесі читання завдань;

3) залучення вже накопичених знань i досвіду передбачає здатність співвідносити попередній читацький досвід 3 вимогами нової ситуації, уміння свідомо знаходити подібне між характеристиками актуального завдання й тих, які були успішно вирішено в минулому;

4) регуляція попередніх знань i досвіду передбачає здатність використовувати набуті знання й досвід для самоосвіти, відкриття нових креативних шляхів для успішного розв'язання встановлених завдань;

5) регуляція стратегій базується на здатності «підбирати» найбільш доречні, найбільш ефективні 3 них, відповідно до специфіки завдань;

6) регуляція дій (планування, поетапна робота, коригування планів) включає здатність планувати й ставити цілі, підбирати оптимальні стратегії їх досягнення, передбачення варіантів розвитку подій у процесі розв’язання проблемної ситуації;

7) оцінювання кожного етапу полягає в співвіднесенні кожного пройденого етапу 3 планом i кінцевою метою суб'єкта когнітивної діяльності;

8) оцінка ефективності обраних стратегій полягає у формуванні суб'єктивного судження про успішність вирішення 
завдання й цінності цього досвіду в плані психоінтелектуального розвитку мовної особистості.

Третій блок - «Рефлексивний» - спрямовано на оцінку оволодіння техніками швидкого читання й розуміння наукового тексту, узагальнення набутого досвіду, оцінку досягнень користувачів програми, планування можливостей застосування набутих знань i вмінь у використанні метакогнітивних стратегій.

\section{Висновки}

Читання є провідним видом активності студентів у оволодінні професією. Розуміння наукового тексту є, в свою чергу, одним із ключових завдань читання студентами вищого навчального закладу й обгрунтовується нами як опосередкований аналітико-синтетичний процес мислення, який містить у собі виділення смислових одиниць й об'єднання їх у єдине контекстуальне ціле, процес і результат когнітивно-креативної діяльності мовної особистості.

Метакогнітивні стратегії в психології та психолінгвістиці розглядаються як стратегії, що регулюють пізнавальну діяльність студентів вищих закладів освіти. Функціями метакогнітивних стратегій $\epsilon$ : цілеполагання, планування, моніторинг, оцінка й контроль пізнавальної діяльності.

Активне застосування метакогнітивних стратегій управління власною пізнавальною діяльністю, усвідомлення процесу застосування цих стратегій позитивно пов'язане зі здатністю до розуміння наукових текстів і може розглядатися як детермінанта такої здатності. Оволодіння різними метакогнітивними стратегіями, їхня варіативність передбачає знання й розуміння структури тексту, його різновидів, високу здатність до розуміння тексту та множинність різних метакогнітивних операцій під час роботи 3 текстовим науковим матеріалом.

Металінгвістичні здібності студентів вищих навчальних закладів можуть розглядатися як інтеграція зусиль і здібності до розуміння наукових текстів.

Здатність студентів до рефлексії власної навчально-професійної діяльності позитивно пов'язана 3 досвідом до зосередженої, вдумливої роботи з текстовим матеріалом і вмінням опрацьовувати 
Metacognitive Strategies of Developing the Reading Competence...

складні наукові тексти. Запропонована методика SQ3R-це техніка, яка спрямована на якісне засвоєння текстової інформації. Вона допомагає отримати максимальну користь від читання, структурувати й осмислювати інформацію яку вивчають студенти. Знайти й запам'ятати інформацію, яка відповідає завданням. Це метод, який допомагає витягнути із читання тексту необхідну інформацію. Метод використовують у випадках, коли читають не стільки для власного задоволення, скільки для справи, зокрема, для навчання метокогнітивним стратегіям читання наукових текстів.

Формулюючи загальні висновки щодо оцінки стану запропонованої проблеми, зазначимо, що $є$ мало вивченими такі аспекти, як метакогнітивні стратегії в читанні наукових текстів i роль металінгвістичних здібностей у їхньому розвиткові. Роботу над проблемою буде продовжено в напрямку більш глибокої розробки психолінгвістичних аспектів діагностики метакогнітивних стратегій читання наукових текстів, а також втілення в практику навчання студентів запропонованої нами «Програми розвитку метакогнітивних стратегій у роботі 3 науковими текстами». Результати експериментальної роботи планується надалі опублікувати.

\section{Література}

Богин, Г.И. (1989). Схема действий читателя при понимании текста. Калинин.

Выготский, Л.С. (2000). Мысль и слово. Психология. Москва: Изд-во ЭКСМОПресс.

Залевская, А.А. (2005). Психолингвистические исследования. Слово. Текст. Москва: Гнозис.

Зимняя, И.А. (2001). Лингвопсихология речевой деятельности. Москва: Моск. психол.-соц.ин-т; Воронеж: НПО «МОДЭК».

Костюк, Г.С. (1988). Избранныле психологические труды. Киев: «Педагогика».

Красных, В.В. (2001). Основы психолингвистики и теории коммуникации. Москва: ИТДГК «Гнозис».

Кузнецова, Г.А. (2004). Формирование стратегической компетенции в процессе обучения чтению в лицеях и гимназиях. Дисс. канд. пед. наук. Москва.

Лазарева, О.В. (2012). Формирование метакогнитивной регуляции понимания научного текста. [Электронный журнал]. Режим доступа: http://emissia.org/ offline/2012/1843.htm

Леонтьев, А.А. (2003). Основы психолингвистики. Москва: Смысл; СПб: Лань.

Микк, Я.А. (1981). Оптимизация сложности учебного текста. Москва: «Просвещение».

Наролина, В.И. (1982). К проблеме уровней понимания. Вопросы психологии, 6, $125-127$. 
Пирвердиева, Ю.А. (2011). Модели использования инфокоммуникационных технологий в процессе формирования когнитивного компонента металингвистической компетенции лингвиста-преподавателя. Дисс. канд. пед. наук. Ставрополь.

Рубинштейн, С.Л. (2000). Основы общеей психологии. Санкт-Петербург: «Питер».

Сметанникова, Н.Н. (2005). Стратегиальный подход $\kappa$ обучению чтению (междисииплинарные проблемь чтения и грамотности). Москва: «Школьная библиотека».

Чепелева, Н.В. (1992). Психология чтения учебной и научной литературы в системе профессиональной подготовки студентов. Дисс. д-ра психол. наук. Киев.

Alenizi, K., \& Alanazi, M. (2016). The Effectiveness of Metacognitive Teaching Strategies to Enhance Elementary School Pupils' Reading Skills in the Northern Border Areas of Saudi Arabia. International Journal of English Linguistics, 6(4), 213-226. https://doi.org/10.5539/ijel.v6n4p213

Bimmel, P., \& Rammpilon, U. (2000). Lernautonomie und Lernstrategien. Munchen [in German].

Carell, P.L. Gajdusek, L. \& Wise, T. (1998). Metacognition and EFI/ESL reading. Instructional Science, 26, 97-112. https://doi.org/10.1023/A:1003092114195

Chen, A.-Y. (1992). On improving reflective thinking through teacher education. Paper presented at the Annual Meeting of the American Educational Research Association (pp. 248-302). San Francisco.

Denton, C., Wolters, Ch., York, M., Swanson, E., Kulesz, P., \& Francis, D. (2015). Adolescents' use of reading comprehension strategies: Differences related to reading proficiency, grade level, and gender. Learning and Individual Differences, 37, 81-95. https://doi.org/10.1016/j.lindif.2014.11.016

Elvinia, A., \& Ocana de Castro, M. (2017). The Use of Metacognitive Strategies to Enhance Reading Comprehension Skills. Cuadernos de Linguistica Hispanica, 29, 223-244 [in Spanish].

Ghahari, Sh., \& Basanjideh, M. (2015). Dynamics of Strategies-based Language Instruction: A Study of Reading Comprehension and Problem Solving Abilities via Structural Equation Modeling. RELC Journal, 46(3), 237-253. https://doi. org/10.1177/0033688215595713

Hacker, D.J. (1998). Metacognition: Definitions and empirical foundations. Metacognition in Educational Theory and Practice, 1, 123-134.

Hartman, H.J. (2001). Metacognition in Learning and Instruction: Theory, Research, and Practice. Kluwer Academic Publishers, Dordrecht, the Netherlands.

Hosenfeld, C. (1977). A preliminary investigation of the reading strategies of successful and non-successful second language learners. System, 5(2), 110-123. https://doi. org/10.1016/0346-251X(77)90087-2

Leopold, C., \& Leutner, D. (2015). Improving students' science text comprehension through metacognitive self-regulation when applying learning strategies. Metacognition and Learning, 10(3), 313-346. https://doi.org/10.1007/ s11409-014-9130-2

Mijuskovic, M., \& Simovic, S. (2016). The $21^{\text {st }}$ Century English Language Reading Classroom in Montenegro: the Influence of Metacognitive Strategies on University Students' Attitudes Regarding the Process of Reading in English. Porta Linguarum, 26, 23-36. 
Metacognitive Strategies of Developing the Reading Competence...

Penuela, D. (2018). Using Metacognitive Strategies to Raise Awareness of Stress and Intonation in EFL. Colombian Applied Linguistics Journal, 20(1), 91-104. https:// doi.org/10.14483/22487085.12383

Seamster, T.L., Redding, R.E., Cannon, J.R., Ryder, J.M., \& Purcell, J.A. (1993). Cognitive task analysis of expertise in air traffic control. The International Journal of Aviation Psychology, 3, 257-283. https://doi.org/10.1207/ s15327108ijap0304_2

Shih, Y.-Ch., Chern, Ch.-lan, \& Reynolds, B. (2018). Bringing extensive reading and reading strategies into the Taiwanese junior college classroom. Reading in a Foreign Language, 30, 130-151.

Soodla, P., Jogi, A.-L., \& Kikas, E. (2017). Relationships between teachers' metacognitive knowledge and students' metacognitive knowledge and reading achievement. European Journal of Psychology of Education, 32(2), 201-218. https://doi.org/10.1007/s10212-016-0293-X

Tsalas, N., Paulus, M., \& Sodian, B. (2015). Developmental changes and the effect of self-generated feedback in metacognitive controlled spacing strategies in 7-yearolds, 10-year-olds, and adults. Journal of Experimental Child Psychology, 132, 140-154. https://doi.org/10.1016/j.jecp.2015.01.008

Vaughan, J. \& Estes, T. (1986). Reading and Reasoning Beyond the Primary Grades. Boston, MA: Allyn and Bacon.

\section{References}

Bogin, G.I. (1989). Skhema deistvii chitatelia pri ponimanii teksta [Scheme of the reader's actions in understanding the text]. Kalinin [in Russian].

Vygotskii, L.S. (2000). Mysl i slovo. Psikhologiia [Thought and word. Psychology]. Moscow: Izd-vo EKSMO-Press [in Russian].

Zalevskaia, A.A. (2005). Psikholingvisticheskie issledovaniia. Slovo. Tekst [Psycholinguistic studies. Word. Text]. Moscow: Gnozis [in Russian].

Zimniaia, I.A. (2001). Lingvopsikhologiia rechevoi deiatelnosti [Linguopsychology of speech activity]. Voronezh: NPO «MODEK» [in Russian].

Kostiuk, G.S. (1988). Izbrannye psikhologicheskie trudy [Selected psychological works]. Kyiv: Pedagogika [in Russian].

Krasnykh, V.V. (2001). Osnovy psikholingvistiki i teorii kommunikatcii [Fundamentals of psycholonguistics and theory of communication]. Moscow: ITDGK «Gnozis» [in Russian].

Kuznetcova, G.A. (2004). Formirovanie strategicheskoi kompetentcii v protcesse obucheniia chteniiu v litceiakh i gimnaziiakh [Forming strategic competence in the process of teaching to read in lyceums and classical schools]. Candidate's thesis. Moscow [in Russian].

Lazareva, O.V. (2012). Formirovanie metakognitivnoi reguliatcii ponimaniia nauchnogo teksta [Forming metacognitive regulation of understanding scientific texts]. Retrieved from http://emissia.org/offline/2012/1843.htm

Leontev, A.A. (2003). Osnovy psikholingvistiki [Fundamentals of psycholinguistics]. Moscow: Smysl; SPb: Lan [in Russian].

Mikk, Ia.A. (1981). Optimizatciia slozhnosti uchebnogo teksta [Optimization of difficulty of the educational text]. Moscow: Prosveshchenie [in Rusian]. 
Narolina, V.I. (1982). K probleme urovnei ponimaniia [on the problem of the levels of understanding]. Voprosy psikhologii - Issues of Psychology, 6, 125-127 [in Russian].

Pirverdieva, Yu.A. (2011). Modeli ispolzovaniya infokommunikaczionnikh tekhnologij $\mathrm{v}$ proczesse formirovaniya kognitivnogo komponenta metalingvisticheskoj kompetenczii lingvista-prepodavatelya [Models of using the infocommunication technologies in the process of formation the linguist-teacher's cognitive component of metalinguistic competence]. Doctor's thesis. Stavropol [in Russian].

Rubinshtein, S.L. (2000). Osnovy obshchei psikhologii [Fundamentals of general psychology]. Sankt-Peterburg: Piter [in Russian].

Smetannikova, N.N. (2005). Strategialnyi podkhod $k$ obucheniiu chteniiu (mezhdistciplinarnye problemy chteniia $i$ gramotnosti) [Strategic approach to teaching to read (interdisciplinary problems of reading and literacy)]. Moscow: Shkolnaia biblioteka [in Russian].

Chepeleva, N.V. (1992). Psikhologiia chteniia uchebnoi i nauchnoi literatury v sisteme professionalnoi podgotovki studentov [Psychology of reading of educational and scientific literature in the system of professional training if students]. Doctor's thesis. Kyiv [in Russian].

Alenizi, K., \& Alanazi, M. (2016). The Effectiveness of Metacognitive Teaching Strategies to Enhance Elementary School Pupils' Reading Skills in the Northern Border Areas of Saudi Arabia. International Journal of English Linguistics, 6(4), 213-226. https://doi.org/10.5539/ijel.v6n4p213

Bimmel, P., \& Rammpilon, U. (2000). Lernautonomie und Lernstrategien. Munchen [in German].

Carell, P.L. Gajdusek, L. \& Wise, T. (1998). Metacognition and EFI/ESL reading. Instructional Science, 26, 97-112. https://doi.org/10.1023/A:1003092114195

Chen, A.-Y. (1992). On improving reflective thinking through teacher education. Paper presented at the Annual Meeting of the American Educational Research Association (pp. 248-302). San Francisco.

Denton, C., Wolters, Ch., York, M., Swanson, E., Kulesz, P., \& Francis, D. (2015). Adolescents' use of reading comprehension strategies: Differences related to reading proficiency, grade level, and gender. Learning and Individual Differences, 37, 81-95. https://doi.org/10.1016/j.lindif.2014.11.016

Elvinia, A., \& Ocana de Castro, M. (2017). The Use of Metacognitive Strategies to Enhance Reading Comprehension Skills. Cuadernos de Linguistica Hispanica, 29, 223-244 [in Spanish].

Ghahari, Sh., \& Basanjideh, M. (2015). Dynamics of Strategies-based Language Instruction: A Study of Reading Comprehension and Problem Solving Abilities via Structural Equation Modeling. RELC Journal, 46(3), 237-253. https://doi. org/10.1177/0033688215595713

Hacker, D.J. (1998). Metacognition: Definitions and empirical foundations. Metacognition in Educational Theory and Practice, 1, 123-134.

Hartman, H.J. (2001). Metacognition in Learning and Instruction: Theory, Research, and Practice. Kluwer Academic Publishers, Dordrecht, the Netherlands.

Hosenfeld, C. (1977). A preliminary investigation of the reading strategies of successful and non-successful second language learners. System, 5(2), 110-123. https://doi. org/10.1016/0346-251X(77)90087-2

Leopold, C., \& Leutner, D. (2015). Improving students' science text comprehension through metacognitive self-regulation when applying learning strategies. 
Metacognitive Strategies of Developing the Reading Competence...

Metacognition and Learning, 10(3), 313-346. https://doi.org/10.1007/ s11409-014-9130-2

Mijuskovic, M., \& Simovic, S. (2016). The $21^{\text {st }}$ Century English Language Reading Classroom in Montenegro: the Influence of Metacognitive Strategies on University Students' Attitudes Regarding the Process of Reading in English. Porta Linguarum, 26, 23-36.

Penuela, D. (2018). Using Metacognitive Strategies to Raise Awareness of Stress and Intonation in EFL. Colombian Applied Linguistics Journal, 20(1), 91-104. https:// doi.org/10.14483/22487085.12383

Seamster, T.L., Redding, R.E., Cannon, J.R., Ryder, J.M., \& Purcell, J.A. (1993). Cognitive task analysis of expertise in air traffic control. The International Journal of Aviation Psychology, 3, 257-283. https://doi.org/10.1207/s15327108ijap0304_2

Shih, Y.-Ch., Chern, Ch.-lan, \& Reynolds, B. (2018). Bringing extensive reading and reading strategies into the Taiwanese junior college classroom. Reading in a Foreign Language, 30, 130-151.

Soodla, P., Jogi, A.-L., \& Kikas, E. (2017). Relationships between teachers' metacognitive knowledge and students' metacognitive knowledge and reading achievement. European Journal of Psychology of Education, 32(2), 201-218. https://doi.org/10.1007/s10212-016-0293-x

Tsalas, N., Paulus, M., \& Sodian, B. (2015). Developmental changes and the effect of self-generated feedback in metacognitive controlled spacing strategies in 7-yearolds, 10-year-olds, and adults. Journal of Experimental Child Psychology, 132, 140-154. https://doi.org/10.1016/j.jecp.2015.01.008

Vaughan, J. \& Estes, T. (1986). Reading and Reasoning Beyond the Primary Grades. Boston, MA: Allyn and Bacon.

\section{АНОТАЦІЯ}

Вступ. У статmі розглядаються особливості й переваги використання метакогнітивних стратегій для формування читацької компетентності в студентів вишів гуманітарного профрілю в процесі навчально-професійної підготовки; уточнюється поняття "стратегії читання», визначаються основні структурні компоненти; розглядаються функції метакогнітивних стратегій, їхня роль у роботі з науковими текстами. Розкриваються поняття та значення металінгвістичних здібностей $i$ метакогнітивних стратегій. Представлено теоретичні підходи до метакогнітивних стратегій читання, їхніх функцій і ролі в розумінні наукових текстів. Металінгвістичні здібності розглядаються як інтеграція здатності до розуміння наукових текстів та металінгвістичної обізнаності, ерудиції, тобто сукупність знань про специфріку наукового тексту й уміння працювати з ним. Представлено авторську програму формування метакогнітивних стратегій у роботі з науковими текстами.

Результати та дискусії. Обізнаність у метастратегіях пов'язана зі здатністю до розуміння складного вербального матеріалу наукового характеру. Читач завдяки рефлексії через мовленнєвий досвід й уявлення проникає в інформацію й зміст тексту, досягає його розуміння. Метакогнітивні знання, 
як обізнаність у стратегіях і техніках метапізнання, пов'язані зі здатністю до розуміння складного вербального матеріалу наукового характеру. Активне застосування метакогнітивних стратегій управління власною пізнавальною діяльністю, усвідомленість процесу застосування цих стратегій позитивно пов'язані зі здатністю до розуміння наукових текстів і може розглядатися як детермінанта такої здібності. Оволодіння метакогнітивними стратегіями, їхня варіативність передбачає знання й розуміння структури тексту, його різновидів, належну загальну ерудицію до сприймання тексту й варіативність різних метакогнітивних операцій при роботі з текстовим матеріалом. Металінгвістична обізнаність, тобто сукупність знань про текст і вміння працювати з текстом, дозволяє опанувати різними текстами професійної спрямованості швидко й ефрективно. Металінгвістичні стратегії, а також здатність фахівия до власної професійної діяльності позитивно пов'язані зі здатністю до ерективної роботи з текстовим матеріалом і з умінням обробляти складні наукові тексти.

Ключові слова: стратегії читання, металінгвістичні здібності, метакогнітивні стратегії, читання й розуміння наукових текстів, рефлексія, моніторинг.

\section{Доцевич Тамилия. Метакогнитивные стратегии развития читательской компетентности у студентов высшего учебного заведения}

\section{АННОТАЦИЯ}

Вступление. В статье рассматриваются особенности и преимущества метакогнитивных стратегий в развитии читательской компетентности у студентов вузов гуманитарного профиля в прочессе учебно-профессиональной подготовки; уточняется понятие "стратегии чтения», выделяются основные структурные компоненты; рассматриваются функции метакогнитивных стратегий, их роль в работе с научными текстами. Раскрываются понятия и значения металингвистических способностей и метакогнитивных стратегий. Представлены теоретические подходы к метакогнитивным стратегиям чтения, их функциям, роли в понимании научных текстов. Металингвистические способности могут рассматриваться как интеграция способности к пониманию научных текстов и металингвистической осведомленностью, т.е. совокупностью знаний о тексте и умением работать с текстом. В статье представлена авторская «Программа фоормирования метакогнитивных стратегий в работе с научными текстами».

Результаты и дискуссии. Осведомленность в метастратегиях связана со способностью понимания сложного вербального материала научного характера. Обращается внимание на то, что, благодаря рефрлексии читать через речевой опыт, воображение проникает в содержание текста, достигая его понимания. Показано, что метакогнитивные знания, как осведомленность в стратегиях и техниках метапознания, связаны со способностью к пониманию сложного вербального материала научного характера. Подчеркивается, что активное использование метакогнитивных стратегий 
Metacognitive Strategies of Developing the Reading Competence...

управления собственной познавательной деятельностью, осознанность процесса использования этих стратегий позитивно связаны со способностью к пониманию научных текстов и может рассматриваться как детерминанта такой способности. Обосновано, что овладение метакогнитивными стратегиями, их вариативность предусматривает знания и понимание структуры текста, его разнообразия, высокую способность к пониманию текста и вариативность разных метакогнитивных операций при работе с текстовым материалом. Металингвистическая осведомленность, т.е. совокупность знаний о тексте и умение работать с ним, позволяет овладеть разными текстами профессиональной направленности быстро и эффрективно. Метакогнитивные стратегии, а также способность специалиста к собственной профессиональной деятельности позитивно связаны со способностью к эфрекетивной работе с текстовым материалом и с умением обрабатывать сложные научные тексты.

Ключевые слова: стратегии чтения, металингвистические способности, метакогнитивные стратегии, чтение и понимание научных текстов, рефлексия, мониторинг. 